\title{
DIGITAL TECHNOLOGY IN HIGHER EDUCATION: SITUATION ANALYSIS AND PROSPECTS ASSESSMENT (ON THE EXAMPLE OF KRASNOYARSK KRAI)
}

\author{
V. Efimov, A. Lapteva \\ Siberian Federal University (RUSSIAN FEDERATION)
}

\begin{abstract}
Currently, one of the key processes in the higher education is the "transition to a digital platform", i.e. the development and adoption of digital technologies, solutions and products in the educational process. In the future, several clusters of digital technology in the higher education will be deployed on the basis of data analytics, digital models, artificial intelligence, augmented and virtual reality, and the blockchain.
\end{abstract}

The study addresses the following objectives: 1) development of a structured "map" of digital technology for higher education; 2) assessment of the extent of development and use of digital technologies in the higher education sphere at present (in developed countries and in a separate region of the Russian Federation - Krasnoyarsk Krai); 3) assessment of the prospects for the development and adoption of digital technologies by 2035 (in developed countries and in Krasnoyarsk Krai).

The following research methods were used: 1) a conceptual analysis of scientific publications, forecasts, foresight-studies and analytical reports; 2) expert interviews, 3) a questionnaire based survey (32 experts - researchers, professors, representatives of government and consulting companies).

The following core groups of digital technologies are designated: 1) digital solutions for defining the personal goals of education, educational navigation, building a project for an individual educational trajectory; 2) adaptive educational environment for the implementation of an individual educational trajectory; 3) digital solutions for learning activities support; monitoring the results of education; solutions for educational logistics; 4) digital solutions for assessment and certification (personal identification and competency assessment); 5) digital solutions for career support and lifelong education; 6) digital solutions for building and supporting university communities (including teachers, students, graduates, university partners); 7) digital solutions for monitoring and modeling the dynamics of competences at the population level. Each group includes 3-12 technologies, so it is possible to build a detailed "map" of digital technologies for higher education sphere.

According to the experts, most of the major groups of digital technologies for education are currently (2018) in the stage of "working prototypes and pilot products" and "locally used products" (in the developed countries of the world). The exceptions are "digital solutions for monitoring and modeling the dynamics of competencies at the population level," which are still at the "research and development" stage. By 2030, all technologies of major groups will reach the stage of "mass market products" and "local market products".

The structure of assessments of the digital technology application in the present and prospects for adoption by 2030 for Krasnoyarsk Krai is generally similar to the structure of assessments for developed countries of the world, but the magnitudes of the estimates are much smaller. The result reflects the "catching up" nature of the development of digital technology in the education sphere in the region. The basic strategy of digitalization of higher education in the region will be the transfer of ready-made solutions that have already found wide application in the developed countries of the world.

Keywords: Higher education, digital technology, Krasnoyarsk Krai.

\section{INTRODUCTION}

The transition to the extensive use of digital technologies (digital solutions, products) in the educational process, research and management is currently the mainstream of the modernization of higher education. To manage the development of higher education systems at the country and 
regional levels, at the level of individual universities, it is important to understand the prospects for digital technologies in this field. However, it is not enough to pay attention to most "popular" (most often used and discussed) groups of digital technologies. We need a systematic, holistic picture of the entire field of promising digital technologies, the use of which will transfer the activities of universities to a new level.

In recent decades, digital technologies have an increasingly significant impact on almost all areas of activity and human life in both developed and developing countries. An increasing share of value in the economy is created by the use of digital technologies, which makes it possible to speak about the formation of a "digital economy" [1, 2]. A generation of people grows up who cannot imagine their life without electronic "gadgets" as mobile phones, laptops, tablets, etc. One can speak of a "digital person" for whom digital technologies are tightly integrated both in professional activity and in the fabric of everyday life.

The digital revolution is changing the reality surrounding universities and changing universities themselves. Its impact on humanity will be no less significant than the impact (civilizational consequences) of the printed revolution (the ability to replicate and spread knowledge and ideas in the form of a "printed word"; create a mass education system).

The connection of university changes with total "digitalization" of the economy and society and the university itself has become a generally accepted idea $[3,4,5,6,7,8,9]$. The various components of digitalization of higher education are discussed: e-learning resources, online education $[10,11,12,13$, 14, 15, 16]; administration using digital technologies - electronic document circulation, etc. [17]; "gamification" of training, use of simulators, augmented reality, virtual reality $[18,19]$; the use of mobile devices [20]; the formation of competencies necessary in the digital world [21]; collecting and analyzing "big data" about students and the educational process [22]. In Russia, a project of a "fully digital" university is being initiated - a digital platform for the formation of individual educational trajectories [23]. Regarding the future, the consulting company Gartner annually presents the Hype Cycle scheme, which reflects the dynamics of the development of digital technologies in the field of education [24].

The subject of this publication is the prospects for the use of digital technologies in the educational activities of higher education institutions in the Russian region - Krasnoyarsk Krai. The results of the study of the prospects for the use of digital technologies in research and university management will be presented in other publications.

The specificity of Krasnoyarsk Krai as a region of the Russian Federation is that it is a large industrial one; it has a powerful scientific and educational complex, which consists of 35 higher education organizations, including 10 state universities (and 15 branches), 1 non-state university, 10 branches of non-state universities.

\section{METHODOLOGY}

\subsection{Conceptual Analysis}

To build a structured "map" of digital technologies that can be used in educational activities in higher education, the conceptual analysis has been applied: the structure of higher education activities has been arranged, and the corresponding technology groups have been formed on the basis of this structure. The final task of the conceptual work is to achieve a comprehensive vision of groups of promising technologies.

\subsection{Expert Survey}

To assess the extent of development and use of digital technologies in the world and in the region, a standardized survey of experts was applied using a specially designed questionnaire. 32 experts took part in the survey, including researchers and university professors, representatives of government and consulting companies.

Experts were asked to assess the extent of development and use of different groups of digital technologies in higher education at present and in the future until 2030:

1 in the developed countries of the world in 2018 (at present);

2 in the developed countries of the world in 2030 (in the future); 
3 in Krasnoyarsk Krai in 2018 (at present);

4 in Krasnoyarsk Krai in 2030 (in the future).

To assess the extent of development and use of different groups of digital technologies in higher education in the developed countries of the world at present (2018) and in the future (2030), experts used the following five-point scale:

- 1 point - there are no digital technologies and products (there are no prototypes, pilot projects, there are no preliminary developments);

- 2 points - research and development is being conducted, on the basis of which digital technologies and products will be created;

- 3 points - there is a working prototype or pilot project;

- 4 points - a market locally used product has been created;

- 5 points - a market product (software solution, technology, etc.) that has been massively used in educational practice has been created.

To assess the extent of use of different groups of digital technologies in higher education in Krasnoyarsk Krai at present (2018), the following five-point scale was proposed:

- 1 point - digital technologies and products are not known and are not applied;

- 2 points - technologies are known, but not applied;

- 3 points - digital technologies are used at separate pilot sites;

- 4 points - technologies are used by individual organizations;

- 5 points - there is a large-scale, massive use of digital technologies in the field of higher education.

To assess the prospects of different groups of digital technologies for adoption in higher education sphere of Krasnoyarsk Krai in the period up to 2030, the following five-point scale was proposed:

- 1 point - not promising;

- 2 points - not very promising;

- 3 points - moderately promising;

- 4 points - highly promising;

- 5 points - having excellent prospects.

These scales are the basis for interpretation of the average scores of the expert estimates (the arithmetic average of all estimates for each position).

\section{RESULTS}

\subsection{Conceptual analysis results}

The structure of activities in higher education includes the following main components:

1 Definition of educational goals; educational navigation; creation of a project of an individual educational trajectory.

2 Realization of an individual educational trajectory.

3 Support for educational activities; educational logistics; monitoring of educational outcomes.

4 Competency assessment and certification.

5 Career support and lifelong education.

6 Building and supporting university communities (including teachers, students, graduates, university partners).

7 Monitoring and modeling of the dynamics of competences at the population level (population of a region, country, etc.). 
In accordance with the structure of the activities, the following core groups of digital technologies were identified for the sphere of higher education.

1 Digital solutions for determining the goals of education, educational navigation, conceiving the project of an individual educational trajectory.

2 Adaptive educational environment for the implementation of an individual educational trajectory.

3 Digital solutions for learning activities support; educational logistics; monitoring the outcomes.

4 Digital solutions for assessment and certification (personal identification and competency assessment).

5 Digital solutions for career support and lifelong education.

6 Digital solutions for building and supporting university communities.

7 Digital solutions for monitoring and modeling the dynamics of competences at the population level.

Each core group includes various digital technologies (existing and possible in the future), which can be used in educational activities in higher education; the "map" of technologies includes the following items.

1 Digital solutions for determining educational goals, educational navigation, conceiving the project of an individual educational trajectory (on the base of cross-cutting technologies as Big Data, Artificial Intelligence (AI), virtual reality, robots).

1.1. "Digital portrait" - an educational history of the student, including his/her interests, achievements, general and special competencies, electronic portfolio.

1.2. Online solutions for interactive diagnostics of general and special competencies, interests, motivation, including online tests, diagnostics using computer games, diagnostics on the base of actions in virtual reality (simulators, virtual worlds, etc.).

1.3. Digital model of educational space: catalogues of educational institutions (universities, colleges, etc.), online courses and modules, Internet sites, etc.; electronic maps of educational resources (spaces for possible educational trajectories); digital images of future professions (films, interviews, texts, digital characters, etc., showing the role in society and the activities of professionals).

1.4. Digital tutor - an individual assistant, which assists with the formulation of educational goals and objectives, navigation in the educational space.

2 Adaptive educational environment for the implementation of an individual educational trajectory (on the base of cross-cutting technologies as digital models, Al, augmented reality, virtual reality, neural interfaces, blockchain, robots).

2.1. Educational content - materials for educational activities including online courses, online modules (packages of digitized texts, problem books, tests, multimedia materials, guidelines); smart libraries (scientific, educational, methodical texts and multimedia resources + tools for search, filtering, accumulation of resources); augmented reality.

2.2. Educational content - environments for educational activities: simulators and trainers, virtual realities for trial activities (virtual laboratories, factories, markets, industrial installations, workplaces, etc.); virtual platforms for communication and discussion, virtual "project teams".

3 Digital solutions for learning activities support; educational logistics; monitoring the outcomes (on the base of cross-cutting technologies as Big Data, digital models, Al, neural interfaces, blockchain, robots).

3.1. Identification and monitoring (tracking and analysis) of student activity: user identification systems (including biometrics, etc.); online tests; electronic portfolio; digital portrait; "digital footprint" of a person; anti-plagiarism systems.

3.2. Student activity support: electronic organizer; digital tutor; personal area of the student.

3.3. Systems of adaptive educational logistics: software for scheduling; curriculum software; systems for building individual educational trajectories (use of educational space and educational resources, academic mobility, etc.). 
4 Digital solutions for assessment and certification (personal identification and competency assessment) (on the base of cross-cutting technologies as Big Data, digital models, Al, virtual reality, blockchain, robots): banks of professional standards in terms of competencies; user identification systems; online tests; competency assessment using computer games; evaluation of competencies on the base of actions in virtual reality (simulators, virtual worlds, etc.).

5 Digital solutions for career support and lifelong education (on the base of cross-cutting technologies as Big Data, digital models, Al, blockchain, robots).

5.1. Identification of a person (user identification systems including biometrics, etc.); competency assessment.

5.2. Employment assistance and career advancement: systems for navigation in the labor market and professional communities; systems of evaluation of personal social, professional, image capital; digital portrait of a professional (professional history, achievements, general and special competences, areas of interest, planned projects); digital tutor for career advancement.

5.3. Lifelong education: navigation systems in educational resources; competency assessment systems and designing individual's own trajectory as a professional and personality; personal digital tutor.

6 Digital solutions for building and supporting university communities, including teachers, students, graduates, university partners (on the base of cross-cutting technologies as Big Data, digital models, virtual reality, Al, blockchain, robots): "digital representations" of persons, groups, project teams, university departments, various organizations; virtual platforms for communication and discussion, platforms for the presentation of ideas (the possibility for everyone to know about everyone, to communicate with everyone); support systems for initiating and implementing projects (organizing work, communication and collaboration in a team, monitoring and assembling intermediate results - virtual project offices).

7 Digital solutions for monitoring and modeling the dynamics of competences at the population level, i.e. students, graduates, the entire population in the city, region, country, world (on the base of cross-cutting technologies as Big Data, digital models, Al): "Big Data" accumulation systems; digital population model in terms of competencies; digital model of the labor market; digital model of socio-economic system (region, country) as a system of activities; data on the "collective intelligence" resource (network communities, "project teams", scientific and engineering schools, etc.) in the region, in the country.

\subsection{The current state and prospects of digital technology for higher education - the results of an expert survey}

The average points of expert estimates for the core groups of digital technologies in higher education in relation to the world (developed countries) in 2018 and in the period up to 2030 are presented in Fig. 1.

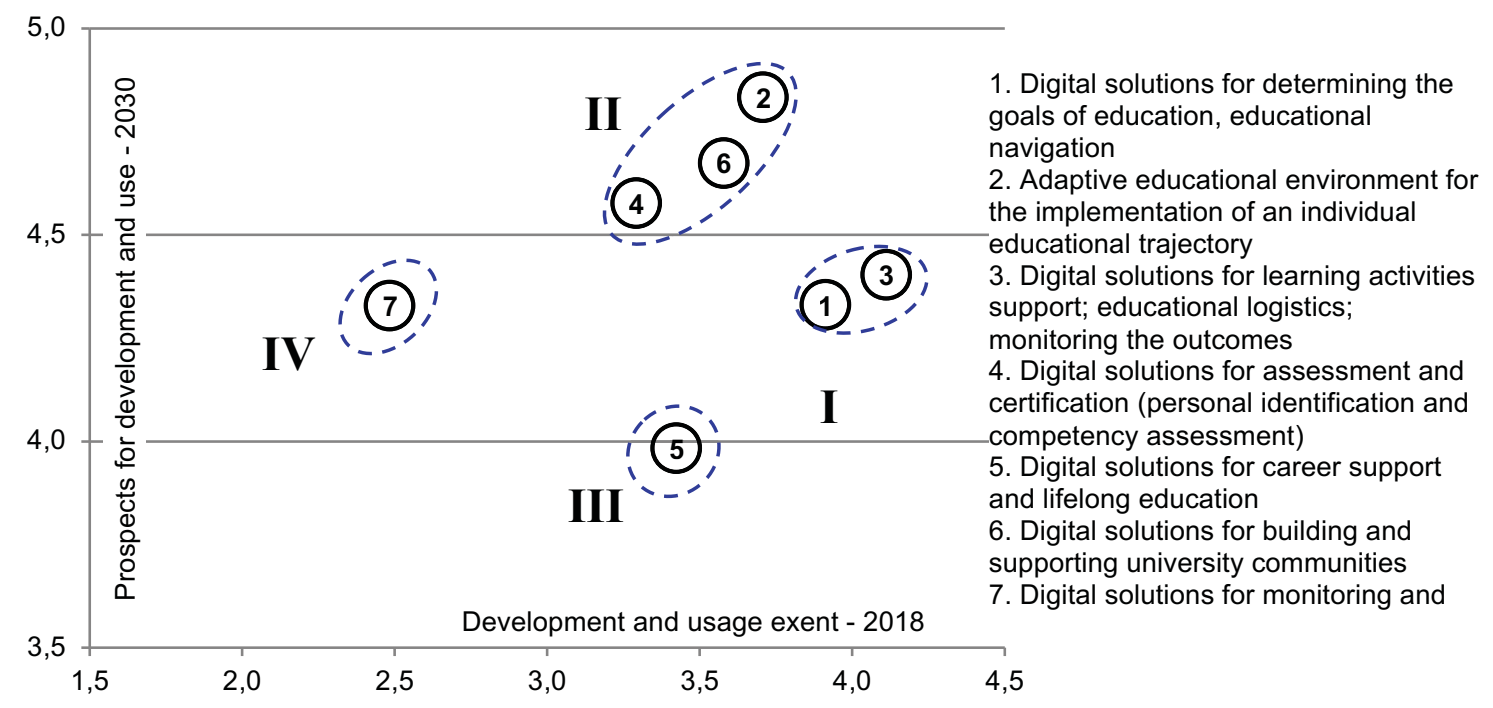

Figure 1. Assessment of the current level (2018) and prospects for the use (2030) in higher education in the world (developed countries) of the core groups of digital technologies 
There are four clusters of technologies in Fig 1.

Cluster I is digital technologies that are currently at the stage of a market product, at least locally used in developed countries (average points of expert estimates are 4 or more for 2018); In the future, up to 2030, these technologies will be increasingly used in the practice of education (4.3-4.5 points for 2030). This cluster includes two core groups of technologies:

- digital solutions for determining the goals of education, educational navigation, conceiving the project of an individual educational trajectory;

- digital solutions for learning activities support; educational logistics; monitoring the outcomes.

Cluster II is digital technologies, which have now passed the stage of pilot projects, the creation of working prototypes and are developing to locally used market products (average points of expert estimates are in the range from 3 to 4 for 2018). In the future up to 2030, they will become massively used in higher education in developed countries - points of expert estimates of more than 4.5 for 2030. This cluster includes three core groups of technologies:

- adaptive educational environment for the implementation of an individual educational trajectory;

- digital solutions for building and supporting university communities;

- digital solutions for assessment and certification (personal identification and competency assessment).

Cluster III is technologies that currently have developed pilot projects, prototypes and partly moved to the level of locally used market products (average points of expert estimates are in the range from 3 to 4 for 2018). However, it is expected that these technologies will evolve more slowly than others in the period up to 2030 and will be ready not for mass, but only for local use (4 points). This cluster includes:

- digital solutions for career support and lifelong education.

Cluster IV is the least developed and currently used technologies that in developed countries are at the stage of R\&D (average points of expert estimates are less than 2.5 for 2018). In the future, up to 2030 , it is expected that corresponding digital technologies will be created, which will be used first in local markets (more than 4 points for 2030). This cluster includes:

- digital solutions for monitoring and modeling the dynamics of competences at the population level.

The average points of expert estimates for the core groups of digital technologies in higher education in Krasnoyarsk Krai (in 2018 and in the long term to 2030) are shown in Fig. 2
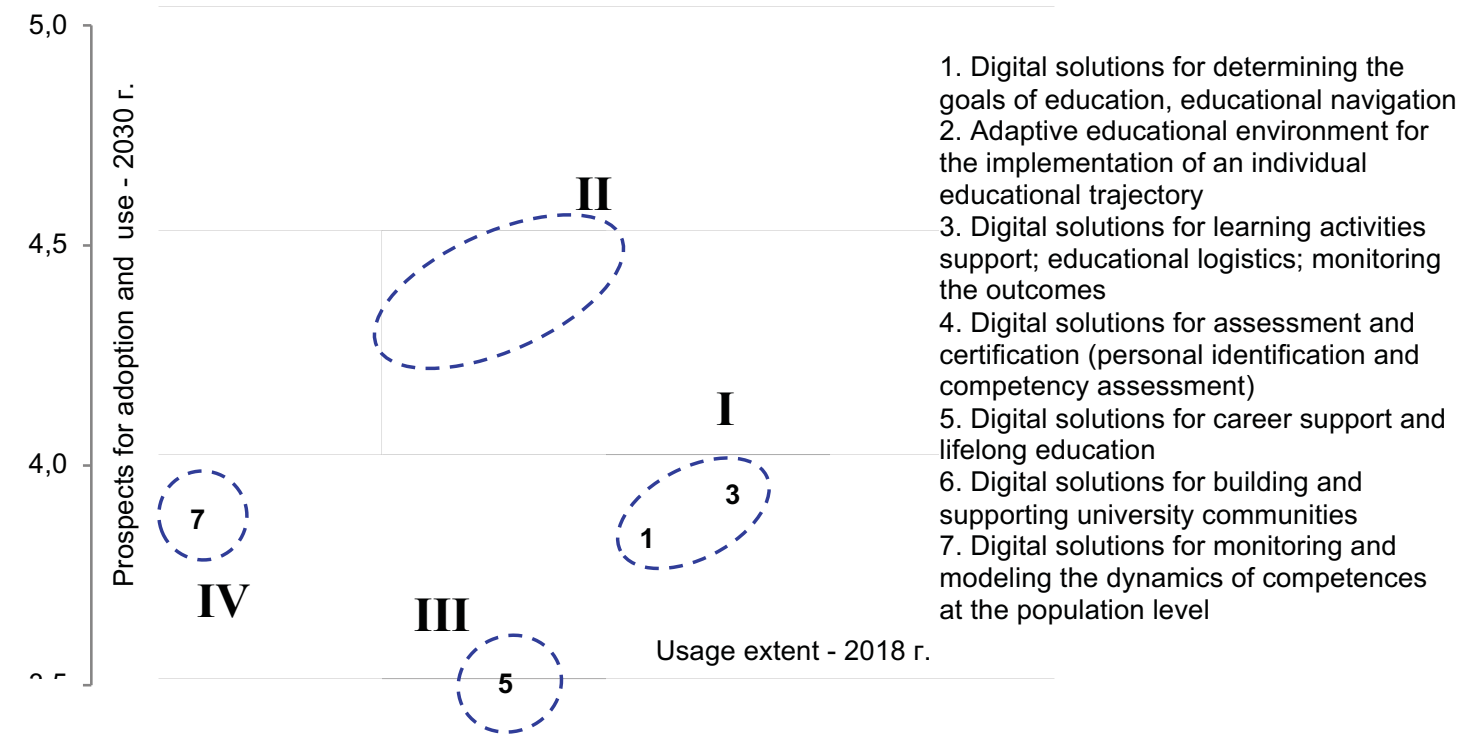

Figure 2. Assessment of the current level (2018) and prospects for use (2030) in the higher education in Krasnoyarsk Krai of the main groups of digital technologies 
The assessment structure for Krasnoyarsk Krai is generally similar to the same for the world, but the magnitude of the points is less, reflecting the "catching up" nature of digital technology adoption in the region - development through transfer of technologies, which has already found extensive use in the world.

Cluster I includes the same core digital technology groups:

- digital solutions for determining the goals of education, educational navigation, conceiving the project of an individual educational trajectory;

- digital solutions for learning activities support; educational logistics; monitoring the outcomes.

Estimates close to 3.5 points mean the use of these technologies in 2018 at universities at certain pilot sites and the transition to use in certain educational organizations. Estimates of prospects for the period up to 2030 are in the range of 3.8-4 points, so these groups of technologies are estimated by experts as highly promising for the region in the next $10-15$ years.

Cluster II includes:

- technologies of an adaptive educational environment for the implementation of an individual educational trajectory;

- digital solutions for building and supporting university communities;

- digital solutions for assessment and certification (personal identification and competency assessment).

Estimates from 2.5 to a little more than 3 points mean that these technologies are not used in 2018 , or are used on separate pilot sites. The prospects of these technologies until 2030 are estimated at 4.34.5 points, so these groups of technologies can be considered highly promising for the region in the future.

Cluster III includes one group of technologies:

- digital solutions for career support and lifelong education.

The average estimate for 2018 is less than 3 points, thus these technologies are practically not used in higher education in the region. The prospects of this technologies until 2030 are estimated at 3.5 points, which corresponds to the average degree of technology prospects for the region in the future.

Cluster IV also includes one group of technologies:

- digital solutions for monitoring and modeling the dynamics of competences at the population level.

The average estimate for 2018 is less than 2 points, so these technologies are not only not used, but are also unknown in the region. The prospects of this technology until 2030 are estimated at about 4 points, which corresponds to a high degree of technology prospects for the region in the future.

\section{CONCLUSIONS}

In accordance with the structure of the activities in the sphere of higher education, the following core groups of digital technologies are designated: 1) digital solutions for defining the personal goals of education, educational navigation, building a project for an individual educational trajectory; 2) adaptive educational environment for the implementation of an individual educational trajectory; 3 ) digital solutions for learning activities support; monitoring the results of education; solutions for educational logistics; 4) digital solutions for assessment and certification (personal identification and competency assessment); 5) digital solutions for career support and lifelong education; 6) digital solutions for building and supporting university communities (including teachers, students, graduates, university partners); 7) digital solutions for monitoring and modeling the dynamics of competences at the population level. Each group contains a variety of technologies, so it is possible to build a detailed "map" of digital technologies for higher education sphere.

According to the experts, the majority of the core groups of technologies for higher education in 2018 in the developed countries of the world are in the stage of "working prototypes and pilot products" and "market locally used products". The exception is "digital solutions for monitoring and modeling the dynamics of competencies at the population level," which are still at the research and development 
stage. In general, by 2030 all the technologies of the core groups will evolve to the stage of "mass market products" and "local market products".

The assessment structure for Krasnoyarsk Krai (in the present and by 2030) is basically similar to the assessment structure for the world (developed countries), but the estimates are lower. The result reflects the "catching up" nature of the development of digital technologies in higher education in the region - through the transfer of ready-made solutions that have already found wide application in the developed countries of the world.

\section{ACKNOWLEDGEMENTS}

The study was funded by Russian Foundation for Basic Research, Krasnoyarsk Region Science and Technology Support Fund (the research project "Regional "intellectual ecosystem" (R\&D, education, innovation) for the Krasnoyarsk Krai: a scientific and methodological analysis of new opportunities for education, research and innovation in the digital world frame; development of a system model for the "intellectual ecosystem" of the region; development of a digital platform as the basis for this ecosystem” №18-410-242007).

\section{REFERENCES}

[1] The World Bank, World Development Report 2016: Digital Dividends. Washington, International Bank for Reconstruction and Development / The World Bank, 2016.

[2] E.V. Ustyuzhanina, A.V. Sigarev, R.A. Shein, "Tsifrovaya revolyutsiya i fundamental'nye izmeneniya $v$ ekonomicheskikh otnosheniyakh [Digital revolution and fundamental changes in economic relations]", Vestnik Chelyiabinskogo gosudarstvennogo universiteta [Bulletin of the Chelyabinsk State University], vol. 406, no. 10, Ekonomicheskie nauki [Economic sciences], Issue 58, pp. 15-25, 2017.

[3] B. Collis, J. Moonen, Flexible Learning in a digital world: experiences and expectations. London, New York: Routledge, 2006.

[4] Trends in Higher Education Marketing, Recruitment, and Technology. Washington: Hanover Research, 2014.

[5] E.V. Neborskii, "Obrazovanie budushchego: klyuchevye pedagogicheskie innovatsii i tendentsii v razvitii obrazovatel'noi sredy [Education of the future: key pedagogical innovations and trends in the development of the educational environment]", Internet-Zhurnal "Naukovedenie" [Internetjournal "Sociology of science"], vol. 7, no. 2, 10 pp, 2015. DOI: 10.15862/166PVN215

[6] G. Siemens, D. Gašević, Sh. Dawson, Preparing for the digital university: a review of the history and current state of distance, blended, and online learning. Athabasca University, University of Edinburgh, University of Texas Arlington, University of South Australia, 2015.

[7] L. Johnson, S. Adams Becker, M. Cummins, V. Estrada, A. Freeman, C. Hall, NMC Horizon Report: 2016 Higher Education Edition. Austin, Texas: The New Media Consortium, 2016.

[8] Trends Shaping Education 2016. Paris: OECD Publishing, 2016. Retrieved from http://dx.doi.org/10.1787/trends_edu2016-en

[9] T.V. Nikulina, E.B. Starichenko, "Informatizatsiya i tsifrovizatsiya obrazovaniya: ponyatiya, tekhnologii, upravlenie [Informatization and digitalization of education: concepts, technologies, management]", Pedagogicheskoe obrazovanie v Rossii [Pedagogical education in Russia], no. 8, pp. 107-113, 2018,

[10] Kyong-Jee Kim, Curtis J. Bonk, "The Future of Online Teaching and Learning in Higher Education: The Survey Says...", Educause quarterly, no. 4, pp. 22-30, 2006.

[11] M. Shachar, Y. Neumann, "Twenty Years of Research on the Academic Performance Differences Between Traditional and Distance Learning: Summative Meta-Analysis and Trend Examination", MERLOT Journal of Online Learning and Teaching, vol. 6, no. 2, pp. 318-334, 2010.

[12] J.L. Moore, C. Dickson-Deane, K. Galyen, "E-Learning, online learning, and distance learning environments: Are they the same?", Internet and Higher Education, no. 14, pp. 129-135, 2011. 
[13] B. Cheawjindakarn, P. Suwannatthachote, A. Theeraroungchaisri, "Critical Success Factors for Online Distance Learning in Higher Education: A Review of the Literature", Creative Education, vol. 3, Supplement, pp. 61-66, 2012.

[14] T.R. Liyanagunawardena, A.A. Adams, S.A. Williams, "MOOC: A Systematic Study of the Published Literature 2008-2012. The International Review of Research", Open and Distance Learning, no. 14(3), pp. 202-227, 2013.

[15] Onlain-obuchenie: kak ono menyaet strukturu obrazovaniya i ekonomiku universiteta. Otkrytaya diskussiya Ya.I. Kuz'minov - M. Karnoi [Online learning: how it changes the structure of education and the economy of the university. Open discussion Ya. I. Kuzminov - M. Carnoy], Voprosy obrazovaniya [Educational Studies Moscow], no. 3, pp. 8-43, 2015.

[16] T.V. Semenova, K.A. Vilkova, I.A. Shcheglova, "Rynok massovykh otkrytykh onlain-kursov: perspektivy dlya Rossii [The market of massive open online courses: prospects for Russia]", Voprosy obrazovaniya [Educational Studies Moscow], no. 2, pp. 173-197, 2018.

[17] E.A. Sokolov, S.N. Sereda, "Informatsionnyi servis elektronnogo dokumentooborota vuza [Information service for electronic document flow of the university]", Sovremennye problemy nauki I obrazovaniya [Modern problems of science and education], no. 5, pp. 106-125, 2012.

[18] M.D. Hanus, J. Fox, "Assessing the effects of gamification in the classroom: A longitudinal study on intrinsic motivation, social comparison, satisfaction, effort, and academic performance", Computers and Education, no. 80, pp. 152-161, 2015. DOI: 10.1016/j.compedu.2014.08.019

[19] V. Potkonjak, M. Gardner, V. Callaghan, P. Mattila, Ch. Guetl, V.M. Petrović, K. Jovanović, "Virtual laboratories for education in science, technology, and engineering: A review", Computers \& Education, no. 95, pp. 309-327, 2016.

[20] Wen-Hsiung Wu, Yen-Chun Jim Wu, Chun-Yu Chen, Hao-Yun Kao, Che-Hung Lin, Sih-Han Huang. "Review of trends from mobile learning studies: A meta-analysis", Computers \& Education, no. 59, pp. 817-827, 2012.

[21] N.V. Komleva, Professional'naya kompetentnost' kbchnosti v usloviyakh smart-obchshestva [Professional competence of the individual in a smart society]", Otkrytoe obrazovanie [Open education], vol. 21, no. 1, pp. 27-33, 2017.

[22] A. Picciano, The Evolution of Big Data and Learning Analytics in American Higher Education, Journal of Asynchronous Learning Networks, vol. 16, no. 3, pp. 9-20, 2012.

[23] Universitet 20.35 [University 20.35]. Russia, Ekaterinburg: Izdatel'skie resheniya, vol. 34, (Series 05, Russian Fundamental: University for Russia), 2017.

[24] Hype Cycle for Education, 2017. Retrieved from https://www.gartner.com/doc/3769145?ref=unauthreader\&srcld=1-4730952011 